\section{References}

${ }^{1}$ Lee PN. Statistics of smoking in the United Kingdom. (Research paper 1.) 7th ed. London: Tobacco Research Council, 1976

${ }^{2}$ Russell MAH. Low-tar medium-nicotine cigarettes: a new approach to safer smoking. $\mathrm{Br}$ Med $\mathcal{F} 1976 ; \mathrm{i}: 1430-3$.

${ }^{3}$ Jarvis $M$. Less hazardous smoking. In: Greenhalgh RM, ed. Smoking and arterial disease. Bath: Pitman Press, $1981: 293-8$.

- Stepney R. Would a medium-nicotine, low-tar cigarette be less hazardous to health ? Br Med f $1981 ; 283: 1292-6$.

5 Ashton H, Stepney R, Thompson JW. Self-titration by cigarette smokers. Br Med f 1979;ii:357-60.

- Spence VA, Ho-Yen DO. Puff volume increases when low-nicotine cigarettes are smoked. $\mathrm{Br} \mathrm{Med} \mathcal{F} 1981 ; 283: 730-1$.

7 Wald N, Howard S, Smith PG, et al. Association between atherosclerotic disease and carboxyhaemoglobin levels in tobacco smokers. $\mathrm{Br} \mathrm{Med} \mathcal{f}$ $1973 ; \mathrm{i}: 761-5$

${ }^{8}$ Greenhalgh RM. Biochemical abnormalities and smoking in arterial ischaemia. In: Bergan JJ, Yao JST, ed. Gangrene and severe ischaemia of the lower extremities. New York: Grune and Stratton, 1978

${ }^{9}$ Hughson WG, Mann JI, Tibbs DJ, Woods HF, Walton I. Intermittent claudication: factors determining outcome. $\mathrm{Br}$ Med $\mathcal{F}$ 1978;i:1377-9.

${ }^{10}$ Kirk CJC, Lund VJ, Woodcock NE, Greenhalgh RM. The effect of advice to stop smoking on arterial disease patients, assessed by serum thiocyanate levels. 7 Cardiovasc Surg (Torino) $1980 ; 21: 568-9$.

${ }^{11}$ Kirk CJC, Woodcock NE, Lund VJ. The effect of advice to stop smoking on arterial patients assessed by serum thiocyanate levels. In: Greenhalgh RM, ed. Smoking and arterial disease. Bath: Pitman Presc, 1981:118-21.

12 Feyerabend C, Russell MAH. Improved gas-chromatographic method and micro-extraction technique for the measurement of nicotine in biological fluids. F Pharm Pharmacol 1979;31:73-6.

13 Turner JAMcM, Bell KP, Sillett RW. Deception among cigarette smokers In: Greenhalgh RM, ed. Smoking and arterial disease. Bath: Pitman Press, $1981: 60-3$.

14 Eisen ME, Hammond EC. The effect of smoking on packed cell volume, red cell counts, haemoglobin and platelet counts. Can Med Assoc $\mathcal{F}$ $1956 ; 75: 520-3$.

15 Sagone AL, Lawrence T, Balcerzak SP. Effect of smoking on tissue oxygen supply. Blood $1973 ; 41: 845-51$.

${ }^{16}$ Isager H, Hagerup L. Relationship betweeen cigarette smoking and high packed cell volume and haemoglobin levels. Scand $\mathcal{F}$ Haematol 1971 8:241-4.

${ }^{17}$ Russell MAH, Jarvis M, Iyer R, Feyerabend C. Relation of nicotine yield of cigarettes to blood nicotine concentrations in smokers. $\mathrm{Br} \mathrm{Med} \mathcal{J}$ $1980 ; 281: 972-6$.

${ }^{18}$ Aronow WS. Effect of non-nicotine cigarettes and carbon monoxide on angina. Circulation 1980;61:262-5.

19 Calverley PMA, Leggett RJE, Flenley DC. Carbon monoxide and exercise tolerance in chronic bronchitis and emphysema. $\mathrm{Br} M e d \mathcal{F} 1981 ; 283$ 878-80.

(Accepted 30 April 1982)

\title{
Synergy between thinness and intensive sports activity in delaying menarche
}

\author{
JAN P VANDENBROUCKE, A VAN LAAR, H A VALKENBURG
}

\begin{abstract}
In a study to assess the effects of intensive physical activity and thinness on menarche records of 648 girls aged 10-14 were analysed. The girls were classified as thin or not thin on the basis of their body mass index, and whether or not they engaged in intensive sports activity was established. The presence of either thinness or intensive sports activity was associated with roughly a twofold decrease in the proportion of girls who had reached menarche; the presence of both factors was associated with roughly a fourfold decrease. These results did not appear to depend on age.
\end{abstract}

Thus intensive sports activity and thinness appear to have a synergistic effect in delaying menarche.

\section{Introduction}

Two recent reports by Frisch et al ${ }^{2}$ showed an association between intensive physical activity, thinness, and delayed menarche. It is difficult, however, to disentangle the potential effects of thinness and physical activity: the first report described the experience of ballet dancers, in whom both factors occur together, 1 and the second dealt predominantly with college athletes, augmented by only a small control group. ${ }^{2}$ To gain insight into the respective roles of both factors a comparison should be made between equally thin girls who do and do not

\footnotetext{
Institute of Epidemiology, Faculty of Medicine, Erasmus University Rotterdam, PO Box 1738, 3000 DR Rotterdam, The Netherlands JAN P VANDENBROUCKE, MD, MSC, research epidemiologist $A$ vAN LAAR, systems analyst H A VAL K̈ENRIIRG, MD, PHD, professor of epidemiology
}

engage in intensive physical activities, and vice versa. We found such a comparison could be made by reanalysing data previously collected during a population survey. Elsewhere ${ }^{3}$ we showed that the data from this survey are compatible with the hypothesis of an association between thinness and delayed menarche. Here, we have added physical activity to the analysis and looked into the interaction of both factors.

\section{Subjects, methods, and results}

Between 1975 and 1978 a population survey was undertaken in the Dutch town of Zoetermeer, a suburb near the Hague, to determine the prevalence of several chronic diseases and their determinants. Of a total of 13462 invited inhabitants aged 5 and over, 10532 participated. The overall response rate was $78 \%$; in children and adolescents the response rate was $82 \%$ or higher. All participants were measured and weighed in indoor clothing and without shoes. Female subjects, in a part of the survey directed at establishing the prevalence of infections of the lower urinary tract, were asked about their age at menarche. In another part of the survey, directed at cardiovascular risk factors, we collected information about sports activity. In particular, we determined whether a person was engaged in intensive sports activity as a member of a sports club or participated in competition sport, or both.

The records of 648 girls aged 10-14 at the time of sampling were analysed. We classified the girls as being thin or not thin on the basis of the body mass index (weight in $\mathrm{kg} /\left(\right.$ height in $\mathrm{m}$ ) ${ }^{2}$ ), which is regarded as the best weight :height index for obesity. ${ }^{4}$ Thinness was defined as a body mass index of 17 or smaller. Likewise, we constructed yes-or-no categories for intensive sports activity, based on the information about membership of a sports club or participation in competition sport. In all four combinations of these categories we counted the number of girls who had reached menarche at the time of the survey.

The table shows the results. The presence of either thinness or intensive sports activity was associated with roughly a twofold decrease in the proportion of girls who had reached menarche. When both factors were present the decrease was about fourfold. 
Proportions of girls aged 10-14 who had reached menarche according to whether they were thin and indulged in intensive sports activity

\begin{tabular}{|c|c|c|c|c|c|c|}
\hline & & & & $\%$ & $\mathrm{SE}^{*}$ & Proportion \\
\hline $\begin{array}{l}\text { Thin: } \\
\text { Intensive sport } \\
\text { No intensive sport }\end{array}$ & $\therefore$ & 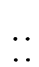 & $\because$. & $\begin{array}{l}15 \\
37\end{array}$ & $\begin{array}{l} \pm 3.4 \\
\pm 4.3\end{array}$ & $\begin{array}{l}16 / 109 \\
47 / 126\end{array}$ \\
\hline $\begin{array}{l}\text { Not thin: } \\
\text { Intensive sport } \\
\text { No intensive sport }\end{array}$ & $\begin{array}{l}\cdots \\
\cdots\end{array}$ & $\begin{array}{l}\cdots \\
\cdots\end{array}$ & $\ddot{n}$ & $\begin{array}{l}47 \\
75\end{array}$ & $\begin{array}{r} \pm 4 \cdot 4 \\
\pm 2 \cdot 6\end{array}$ & $\begin{array}{r}60 / 129 \\
214 / 284\end{array}$ \\
\hline
\end{tabular}

*SE $=$ Standard error

\section{Discussion}

Our data are compatible with the hypothesis that both thinness and physical activity may cause delayed menarche. In addition, the effects of these two factors seem synergistic ${ }^{5}$ : several girls who would have reached menarche if either thinness or intensive sports activity had been present alone had not reached menarche when both factors were present together. Since metabolic changes are probably associated with sports activity and with thinness, synergism of the effects makes sense.

One objection to our analysis is that a certain body mass index might not have the same meaning in a person who is physically active as in a person who is not, owing to different lean:fat ratios. We have no means to correct for this in our data. Other possible objections might be that in subjects aged 10-14 the body mass index rises with age, and that at this critical age drastic changes in physical activity might occur. To take such confounding influences into account we performed the analysis again with smaller age groups, halving the five-year age categorypt The synergistic relation persisted in each of the two resulting age groups. On finer stratification by single years of age thg gradient between the thin and not-thin and sports and no-sports. categories remained in the same direction, though the smallnes( of the numbers made it difficult to judge synergy confidently Thus our data reinforce and refine the earlier hypotheses of Frisch et $a l,{ }^{12}$ particularly since the information was collecte $\$$ during a population survey without obvious selection ang without advance knowledge about the factors entailed in the. hypotheses.

This research was supported by grants from the Netherlands Prevention Fund, the Netherlands Organisation for Applied Scientifi Research, and the Netherlands Kidney Foundation.

\section{References}

1 Frisch RE, Wyshak G, Vincent L. Delayed menarche and amenorrhoea in ballet dancers. $N$ Engl $\mathcal{F}$ Med 1980;303:17-9.

${ }^{2}$ Frisch RE, Gotz-Welbergen AV, McArthur JW, et al. Delayed menarch and amenorrhoea of college athletes in relation to age of onset of training. F $A M A$ A $1981 ; 246: 1559-63$.

${ }^{3}$ Vandenbroucke JP, van Laar A, Valkenburg HA. Thinness, delaye menarche and irregular cycles. $N$ Engl f Med 1981 ;305:229-30.

4 Keys A, Fidanza F, Karvonen MJ, Kimura N, Taylor HL. Indices relative weight and obesity. $\mathcal{F}$ Chronic Dis $1972 ; 25: 329-43$.

${ }^{5}$ Rothman KJ, Greenland S, Walker AM. Concepts of interaction. Am Epidemiol 1980;112:467-70.

(Accepted 28 April 1982)

\title{
Bromocriptine in management of large pituitary tumours
}

\author{
J A H WASS, JULIA WILLIAMS, M CHARLESWORTH, D P E KINGSLEY, A M HALLIDAY, \\ I DONIACH, LESLEY H REES, W I MCDONALD, G M BESSER
}

\begin{abstract}
Bromocriptine has an accepted place in the management of small pituitary tumours that secrete either prolactin or growth hormone. The treatment of large tumours with extrasellar extensions is more difficult, however: though surgery is the standard treatment, it is often unsuccessful in returning excessive hormone secretion to normal and may cause hypopituitarism. A prospective trial was undertaken to assess the frequency with which changes in pituitary function and size of large tumours occurs. Nineteen patients were studied before and during treatment with bromocriptine $(7.5$ to $60 \mathrm{mg} /$ day) for three to
\end{abstract}

\footnotetext{
Departments of Endocrinology, Radiology, and Chemical Endocrinology, St Bartholomew's Hospital, London EC1A 7BE

J A H WASS, MD, MRCP, senior lecturer in medicine JULIA WILLIAMS, SRN, research nurse

M CHARLESWORTH, FRCR, consultant radiologist

D P E KINGSLEY, FRCS, FRCR, consultant radiologist

I DONIACH, MD, FRCP, emeritus professor of pathology

LESLEY H REES, MD, FRCP, professor of chemical endocrinology

G M BESSER, MD, FRCP, professor of endocrinology
}

Institute of Neurology, National Hospital for Nervous Diseases, Queen Square, London WC1

A M HALLIDAY, BSC, $\mathrm{MB}$, consultant neurophysiologist

W I MCDONALD, PHD, FRCP, professor of clinical neurology
22 months, using contrast radiology and a detailed assess? ment of pituitary function. Eighteen patients had hyper prolactinaemia and two of these also had raised concen trations of growth hormone; one patient had an apparent: ly non-functioning tumour. In 12 patients $(63 \%)$ tumour size decreased with bromocriptine and no tumoug enlarged. Nine patients had visual-field defects, which improved in seven, becoming normal in five. Pituitar function improved in nine patients $(47 \%)$ becoming entirely normal in three.

Bromocriptine should be the treatment of choice is patients with large pituitary tumours with extrasellar extensions, provided close supervision is maintained.

\section{Introduction}

Bromocriptine, a long-acting dopamine agonist, lowers abnorma circulating hormone concentrations in patients with smalt pituitary tumours that secrete prolactin and growth hormone? and it has an accepted place in their management. ${ }^{1-6}$ The bes: treatment for large pituitary tumours that extend out of the sellig turcica, however, is more difficult and controversial. Mostly these tumours secrete prolactin though they may be truly non functioning or, more rarely, secrete either growth hormone of adrenocorticotrophin. ${ }^{7}$ Urgent surgical decompression is nor mally recommended if the tumour extends upwards to a a r ect the visual pathways or laterally to affect the oculomotor nerve. 